\title{
ДОСЛІДЖЕННЯ МОРФОЛОГО-АНАТОМІЧНИХ ОЗНАК AJUGA REPTANS L. TPABИ
}

Вступ. Актуальним завданням сучасної фрармації є продовження досліджень лікарської рослинної сировини, яка має багатовіковий досвід використання. Перспективними для фрітотерапії об'єктами є представники роду Горлянка, які традиційно застосовують у науковій та народній медицині багатьох країн при захворюваннях шлунка, сечокам'яній хворобі, отитах, стоматитах, жовчнокам'яній хворобі, запаленні придатків матки, а також як протималярійний засіб та як засіб, що поліпшує обмін речовин. У зв'язку із цим, особливий інтерес викликає вид, склад якого характеризується високим вмістом біологічно активних сполук, що зумовлюють протизапальну, кровоспинну й антиоксидантну дію горлянки повзучої (Ајиgа reptans L.). Рослини роду Горлянка, що ростуть на території України, досліджено недостатньо. Перспективним є вивчення спільних та відмінних морфолого-анатомічних діагностичних ознак будови рослинної сировини досліджуваного виду роду Ajuga R. фрлори України.

Мета дослідження - встановити морфолого-анатомічні ознаки горлянки повзучої трави для виділення основних діагностичних ознак.

Методи дослідження. Для досліджень використовували повітряно-суху та свіжозібрану і фріксовану в суміші гліцерин - етанол - вода (1:1:1) рослинну сировину. Дослідження проводили загальновідомими методами із застосуванням мікроскопів ЛОмO P-1 (Росія) та REICHERT L.4 (Австрія). Отримані дані фріксували за допомогою схематичних рисунків та фротографрій, зроблених фротокамерою Canon A 720 IS.

Результати й обговорення. У результаті проведеного макро- та мікроскопічного аналізу встановлено діагностичні ознаки горлянки повзучої трави.

Висновки. Методом макроскопічного аналізу було досліджено зовнішні ознаки сировини горлянки повзучої і встановлено анатомічні діагностичні ознаки листків трави цієї рослини. Методом мікроскопічного аналізу виявлено слабозвивисті клітини верхнього епідермісу і звивистостінні клітини нижнього епідермісу, діацитний тип продихового апарату; прості волоски; ефріроолійні залозки з великими голівками із 6-8 епітеліальних клітин. Перспективним є використання встановлених основних морфолого-анатомічних діагностичних ознак горлянки повзучої трави для розробки проекту методів контролю якості лікарської рослинної сировини.

КЛЮЧОВІ СЛОВА: горлянка повзуча; морфолого-анатомічні ознаки; листки; стебло; квітки.

ВСТУП. Рід Горлянка родини губоцвіті Lamiaceae, згідно з різними даними, включає близько 50 видів рослин, які поширені по всій земній кулі [1].

Представники роду Горлянка - багаторічні, рідше однорічні, трави або напівчагарники із цілісними трилопатевими чи трироздільними листками. Квітки зібрані в несправжні кільця в пазухах приквіткових листків, схожих на стеблові. Плоди - оберненояйцеподібні, зморшкуваті горішки, прикріплені до квітколожа великою черевною площинкою. Види роду - медоноси, декоративні рослини та агресивні бур'яни. За одними даними, рід налічує близько 40 видів, за іншими - 50 видів, які поширені в Євразії, Північній і Південній Афрриці й Австралії. Поширені (c) С. В. Малюванчук, А. Р. Грицик, М. В. Мельник, 2018. також по всій території України. В нашій країні зростає дев'ять видів горлянки [2].

Горлянка повзуча (Ajuga reptans L.) - це багаторічна трав'яниста рослина родини губоцвіті, яку вперше було представлено в 1653 р. на виставці садівників у м. Лондоні. Має повзуче кореневище й облиснені повзучі пагони [3].

Рослини роду Горлянка широко використовують у народній медицині як лікарські. Вони відомі своїми потогінними, антисептичними, кровоспинними та протизапальними властивостями.

Більшість видів роду Горлянка застосовують при лікуванні вірусних захворювань, простуді, ревматизмі, захворюваннях шлунка, жовчнокам'яній хворобі. Деякі види використовують при малярії та в онкології. Наявність фрлавоноїдів, 
поліфенольних кислот свідчить про антиоксидантну, антибактеріальну та антимікробну дію [4].

Зовнішньо настій горлянки повзучої трави застосовують при опіках, виразках, ранах, захворюваннях ротової порожнини, ангіні та для миття голови при випаданні волосся. Як зовнішній засіб використовують і свіжі подрібнені листки або сік рослини $[5,6]$.

Відомостей про анатомічну будову надземної частини горлянки повзучої в доступних джерелах наукової літератури не виявлено. Тому дослідження анатомічної будови листків і квіток рослини є актуальним.

Мета дослідження - встановити морфолого-анатомічні ознаки горлянки повзучої трави для виділення основних діагностичних ознак.

МЕТОДИ ДОСЛІДЖЕННЯ. Об'єктом дОсліджень була горлянки повзучої трава, заготовлена під час масового цвітіння на території Івано-Франківської області.

Для досліджень використовували повітряно-суху та свіжозібрану і фріксовану в суміші гліцерин - спирт - вода (1:1:1) рослинну сировину. Ознаки її морфологічної будови вивчали загальноприйнятими методами [3]. Сировину розглядали неозброєним оком та за допомогою лупи (×10) при денному освітленні. Анатомічні ознаки органів горлянки повзучої вивчали на відпрепарованій епідермі та препаратах 3 поверхні під мікроскопами лОМО Р-1 (Росія) та REICHERT L.4 (Австрія) (окуляр - ×7, ×10, ×15, об'єктиви - ×10, ×20, ×40). Отримані дані фріксували за допомогою схематичних рисунків та фотографрій, зроблених фротокамерою Canon A 720 IS $[7,8]$.

РЕЗУЛЬТАТИ Й ОБГОВОРЕННЯ. У реЗУЛЬтаті проведених досліджень встановлено, що рослини роду Горлянка подібні за зовнішніми ознаками, що дає можливість виділити найбільш характерні ознаки роду. Відмітні діагностичні ознаки видів роду Горлянка наведено в таблиці.

Морфологічний опис. За зовнішніми ознаками горлянки повзучої трава являє собою цільні або частково подрібнені стебла, листки, квітки. Запах специфічний. Смак гіркий.

Для ідентифікації видів роду Горлянка вивчено анатомічні ознаки вегетативних і генеративних органів. У процесі їх дослідження встановлено відмітні діагностичні ознаки.

Листкова пластинка. Листкова пластинка горлянки повзучої має дорзивентральний тип будови з однорядним палісадним мезофрілом, що складається із сильно видовжених клітин. Губчастий мезофріл багатошаровий, складається з округлих і округло-овальних клітин. Верхня епідерма листкової пластинки складається 3 великих паренхімних клітин, що мають слабозвивисті стінки. У значній кількості на верхній епідермі розміщені прості двоклітинні, рідше триклітинні, товстостінні волоски з бородавчастою кутикулою, рідше спостерігають головчасті волоски на одно- або триклітинній ніжці. Нижня епідерма листкової пластинки складається 3 клітин із сильнозвивистими стінками. Продихи діацитного типу зустрічаються у значній кількості (рис. 1). Вони оточені двома клітинами, рідко трьома і чотирма. На нижній епідермі листка, на відміну від верхньої, розміщені більш короткі прості одно- і двоклітинні волоски. Зустрічаються ефріроолійні залозки з великими голівками із 6-8 епітеліальних клітин, характерними для родини губоцвіті $[7,8]$.

Анатомічна будова пелюстки квітки. При розгляді горлянки повзучої пелюстки квітки на поверхні видно витягнуті з прямими стінками клітини верхнього епідермісу, слабозвивисті клітини нижнього епідермісу (рис. 2).

\section{Таблиця - Відмітні морфологічні ознаки видів роду Горлянка}

\begin{tabular}{|c|c|c|c|}
\hline Назва рослини & Стебло & Листки & К Квітки, плоди \\
\hline $\begin{array}{l}\text { Горлянка } \\
\text { повзуча - } \\
\text { Ajuga } \\
\text { reptans L. }\end{array}$ & $\begin{array}{l}3 \text { а в в и ш к и } \\
\text { 10-35 см, пря- } \\
\text { мостояче, оди- } \\
\text { ничне, нерозга- } \\
\text { лужене, розсія- } \\
\text { новолосисте } \\
\text { лише по двох } \\
\text { протилежних } \\
\text { гранях }\end{array}$ & $\begin{array}{l}\text { Прикореневі листки черешкові, обер- } \\
\text { ненояйцеподібні або овальні, зібрані } \\
\text { в розетку, під час цвітіння рослини не } \\
\text { засихають, з розеток ростуть довгі } \\
\text { вкорінені пагони. Стеблові листки } \\
\text { сидячі, м'які, коротко опушені, оваль- } \\
\text { ні, із зарубчастими або хвилясто-виїм- } \\
\text { частими краями. Приквіткові листки } \\
\text { цільні, яйцеподібні }\end{array}$ & $\begin{array}{l}\text { Квітки неправильні, блакитні (іноді } \\
\text { рожеві або білі), двогубі, розташо- } \\
\text { вані в пазухах листків, зібрані в } \\
\text { мутовках по 6-8 штук, утворюючи } \\
\text { верхівкове колосоподібне суцвіття. } \\
\text { Плоди - горішки довжиною 2,5 мм, } \\
\text { зморшкуваті }[9,10]\end{array}$ \\
\hline $\begin{array}{l}\text { Горлянка } \\
\text { женевська - } \\
\text { Ajuga } \\
\text { genevensis L. }\end{array}$ & $\begin{array}{l}\text { Рівномірно опу- } \\
\text { шене зі всіх сто- } \\
\text { рін, висотою від } \\
5 \text { до } 40 \text { см, але } \\
\text { без повзучих } \\
\text { пагонів }\end{array}$ & $\begin{array}{l}\text { Прикореневі листки видовжено-еліп- } \\
\text { тичні або майже лопатчасті, коротко- } \\
\text { черешкові чи сидячі. Верхівкові лист- } \\
\text { ки трилопатеві, сидячі, синюваті, під } \\
\text { час цвітіння відсутні }\end{array}$ & $\begin{array}{l}\text { Квітки (їх 2-6) в мутовках, непра- } \\
\text { вильні, сині (зрідка рожеві або білі), } \\
\text { зібрані в кільця, що утворюють ко- } \\
\text { лосоподібне суцвіття. Плоди-тем- } \\
\text { но-бурі округлі горішки, сітчасто- } \\
\text { зморшкуваті }[9,10]\end{array}$ \\
\hline
\end{tabular}



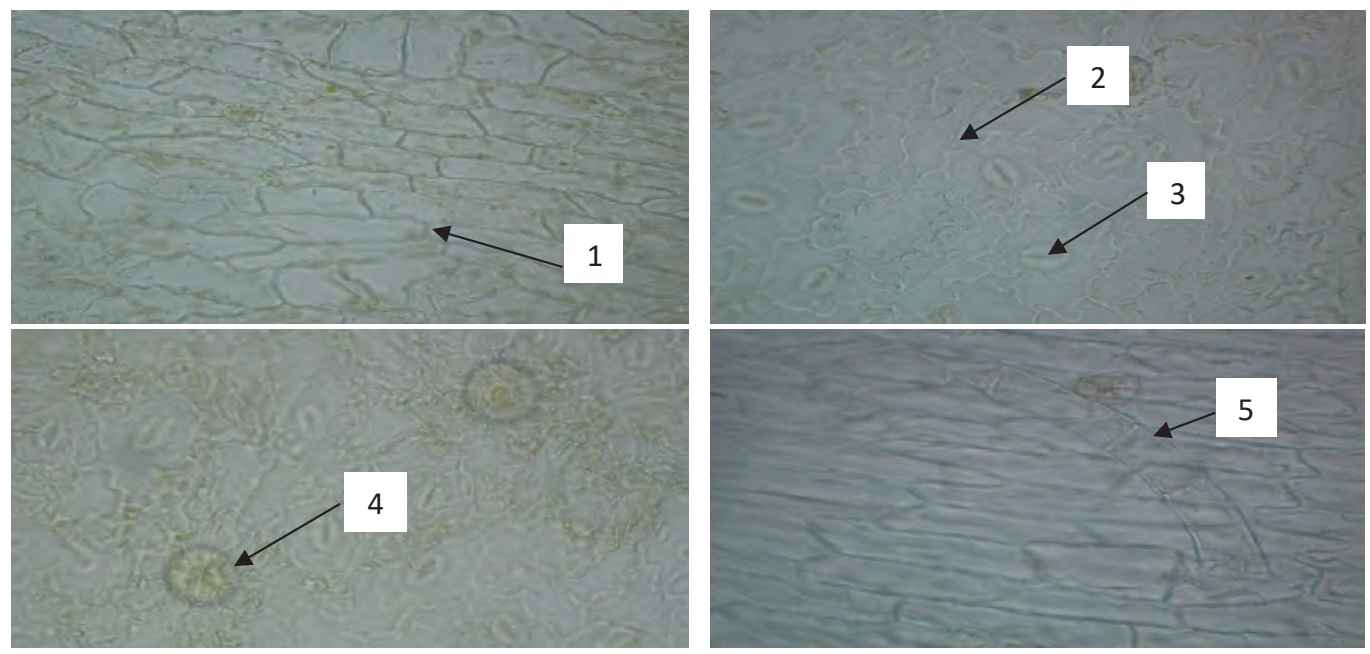

Рис. 1. Анатомічні ознаки горлянки повзучої листка: 1 - клітини верхньої епідерми; 2 - клітини нижньої епідерми; 3 - продихи діацитного типу; 4 - ефріроолійні залозки; 5 - трихоми.
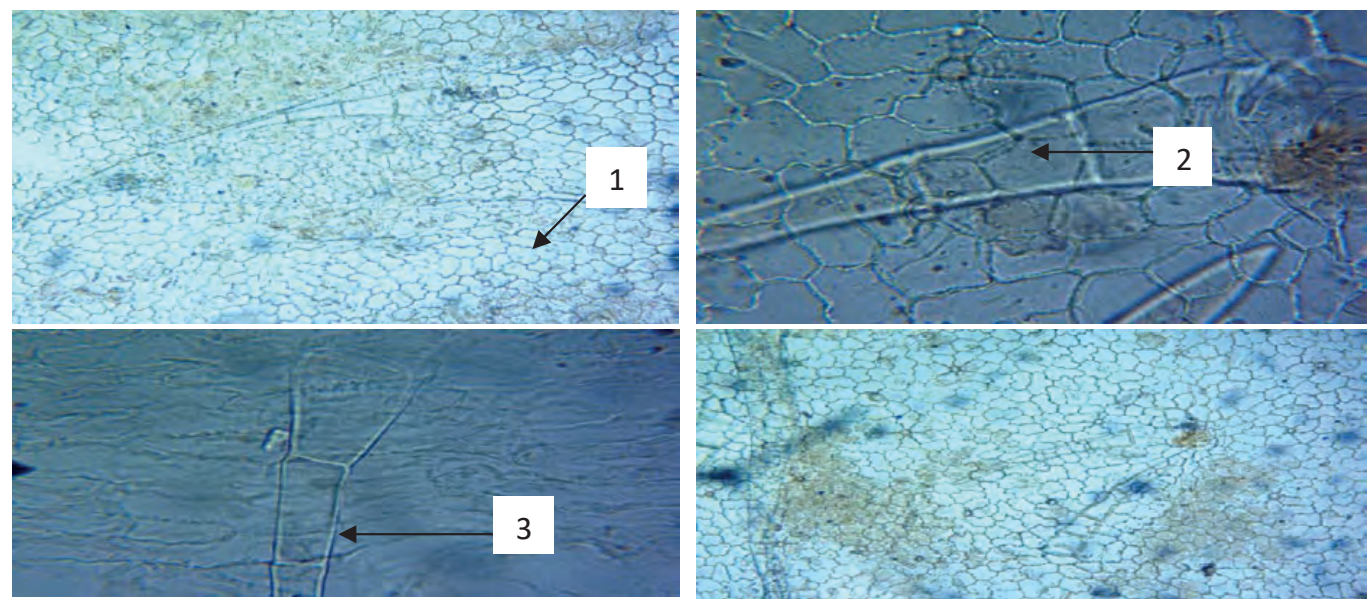

Рис. 2. Анатомічні ознаки горлянки повзучої епідермісу пелюстки квітки: 1 - клітини верхнього епідермісу; 2 - клітини нижнього епідермісу; 3 - трихоми.

Зовнішня епідерма верхньої частини віночка складається з неоднорідних клітин. Біля основи і в середній частині вона складається з прямостінних подовжених уздовж осі клітин, а у верхній частині - 3 ізодіаметричних клітин. У середній частині є довгі прості волоски з однією або двома короткими базальними клітинами.

ВИСНОВКИ. 1. Методом мікроскопічного аналізу вперше було встановлено анатомічні ознаки горлянки повзучої листків трави: слабозвивисті клітини верхнього епідермісу і звивис- тостінні клітини нижнього епідермісу, діацитний тип продихового апарату; прості волоски; ефріроолійні залозки з великими голівками із 6-8 епітеліальних клітин.

2. У результаті проведеного морфологічного аналізу видів роду Горлянка встановлено відмітні їх ознаки: висоту стебла, розмір та форму основи листкової пластинки, будову квітки.

3. Отримані результати буде використано для розробки параметрів стандартизації досліджуваної рослинної сировини.

\section{СПИСОК ЛІТЕРАТУРИ}

1. Флора УРСР / під ред. Д. К. Зерова. - К. : Видавництво Академії наук УРСР, 1960. - IX. С. 294-348.

2. Флора Европейской части СССР / под ред. А. А. Федорова. - Л. : Наука, 1978. - III. - С. 134.
3. Лікарські рослини : енцикл. довід. / відп. ред. А. М. Гродзінський. - К. : Українська енциклопедія ім. М. П. Бажана, 1990. - С. 544.

4. Махлаюк В. П. Лекарственные растения в народной медицине / В. П. Махлаюк. - М. : Военное издательство, 1991. - С. 148-149. 
5. Орач Д. А. Рослини дарують здоров'я : фрітотер. енцикл. довід. / Д. А. Орач, О. Д. Орач ; за ред. К. В. Форманчука. - Львів : Аверс, 2007. - 568 с.

6. Кортиков В. Н. Полная энциклопедия лекарственных растений / В. Н. Кортиков, А. В. Кортиков. Ростов-на-Дону : Феникс, 2008. - 797 с.

7. Сас І. А. Дослідження морфолого-анатомічних ознак видів роду Буквиця (Betonica L.) / I. A. Cac, А. Р. Грицик, М. В. Мельник // Фармац. журн. - 2016. № 3-4. - С. 70-75.

8. Державна Фармакопея України : в 3 т. / Державне підприємство "Український науковий фрармакопейний центр якості лікарських засобів". - 1-ше вид., доп. 4. - Харків : Державне підприємство "Український науковий фрармакопейний центр якості лікарських засобів", 2011. - С. 151-153.

9. Contributions to the phytochemical study of some samples of Ajuga Reptans L. and Ajuga genevensis L. I G. Ghita, O. Cioanca, E Gille [et al.] // Bulletin of the Transilvania University of Brasov Series VI: Medical Sciences. - 2011. - Vol. 4 (53), No. 2.

10. Жигунов О. Ю. Биология некоторых представителей рода Ajuga L. в культуре в Республике Башкорстан / О. Ю. Жигунов, О. А. Каримова // Агрономия и лесное хозяйство. Известия Оренбург. гос. аграр. ун-та. - 2017. - № 1 (63). - С. 31-33.

\section{REFERENCES}

1. Zerov, D.K (Ed.). (1960). Flora USSR [Flora of the Ukrainian SSR]. Kyiv: Vydavnytstvo akademii nauk [in Ukrainian].

2. Fedorov, A.A. (Ed.). (1978). Flora Yevropeyskoy chasti SSSR [Flora of the European part SSSR]. Lviv: Nauka [in Russian].

3. Hrodzinskyi, A.M. (Ed.). (1990). Likarski roslyny: Entsyklopedychnyi dovidnyk [Medicinal plants: Encyclopedic guide]. Kyiv: Ukrainska entsyklopediia im. M.P. Bazhana [in Ukrainian].

4. Makhlayuk, V.P. (1992). Lekarstvennyye rasteniya $\checkmark$ narodnoy meditsine [Medicinal plants in folk medicine] Moscow: Voyennoye izdatelstvo [in Russian].

5. Orach, D.A. (2007). Roslyny daruiut zdorovia: fitoter. entsyklop. dovid. [Plants give health] Phytotherapeutic encyclopaedic handbook]. Formanchuk, K.V. (Ed). Lviv: Avers [in Ukrainian].

6. Kortikov, V.N., \& Kortikov, A.V. (2008). Polnaya entsyklopediya lekarstvennykh rasteniy [Complete encyclopedia of medicinal plants]. Rostov: Phoenix [in Russian].
7. Sas, I.A., Hrytsyk, A.R., \& Melnyk, M.V. (2016). Doslidzhennia morfoloho-anatomichnykh oznak vydiv rodu Bukvytsia (Betonica L.) [The study of anatomo morphological characteristics of genus species Bukvytsya (Betonica L.)]. Farmatsevtychnyi zhurnal - Pharmaceutical Journal, 3-4, 70-75 [in Ukrainian].

8. (2011). Derzhavna Farmakopeia Ukrainy: $v 3 t$. [State Pharmacopoeia of Ukraine: in 3 vol.]. State Enterprise "Ukrainian Scientific Pharmacopoeia Center for the Quality of Medicines" [in Ukrainian].

9. Ghita, G., Cioanca O., Gille E ,, Necula R., Zamfirache, M., \& Stanescu, U. (2011). Contributions to the phytochemical study of some samples of Ajuga Reptans L. and Ajuga genevensis L. Bulletin of the Transilvania University of Brasov, 4 (53).

10. Zhygunov, O.Yu., \& Karimova, O.A. (2017). Biologiya nekotorykh predstaviteley roda Ayuha L. v kulture Respubliky Bashkorstan [Biology of some representatives of the genus Ajuga L. in culture in the Republic of Bashkortostan]. Orenburg: Agrarian University [in Russian].

С. В. Малюванчук, А. Р. Грицык, М. В. Мельнык ИВАНО-ФРАНКОВСКИЙ НАЦИОНАЛЬНЫЙ МЕДИЦИНСКИЙ УНИВЕРСИТЕТ

\section{ИССЛЕДОВАНИЕ МОРФОЛОГО-АНАТОМИЧЕСКИХ ПРИЗНАКОВ ТРАВЫ AJUGA REPTANS L.}

\section{Резюме}

Вступление. Актуальной задачей современной фрармации является продолжение исследований лекарственного растительного сырья, которое имеет многовековой опыт использования. Перспективными для фритотерапии объектами являются представители рода Живучка, которые традиционно применяют в научной и народной медицине многих стран при заболеваниях желудка, мочекаменной болезни, отитах, стоматитах, желчнокаменной болезни, воспалении придатков матки, а также как противомалярийное средство и как средство, улучшающее обмен веществ. В связи с этим, особый интерес вызывает вид, состав которого характеризуется высоким содержанием биологически активных соединений, обусловливающих противовоспалительное, кровоостанавливающее, антиоксидантное действие живучки ползучей (Ajuga reptans L.). Растения рода Живучка, произрастающие на территории Украины, исследовано недостаточно. Перспективным является изучение общих и отличительных морфолого- 
анатомических диагностических признаков строения растительного сырья исследуемого вида рода Ajuga R. фрлоры Украины.

Цель исследования - установить морфролого-анатомические признаки живучки ползучей травы для выделения главных диагностических признаков.

Методы исследования. Для исследований использовали воздушно-сухое и свежесобранное и фриксированное в смеси глицерин - этанол - вода (1:1:1) растительное сырье. Исследование проводили общеизвестными методами с применением микроскопов ЛОМО P-1 (Россия) и REICHERT L.4 (Австрия). Полученные данные фриксировали с помощью схематических рисунков и фротографий, сделанных фротокамерой Canon A 720 IS.

Результаты и обсуждение. В результате проведенного макро- и микроскопического анализа установлено диагностические признаки живучки ползучей травы.

Выводы. Методом макроскопического анализа было исследовано внешние признаки сырья живучки ползучей и установлено анатомические диагностические признаки листьев травы этого растения. Методом микроскопического анализа выявлено слабоизвилистые клетки верхнего эпидермиса и извилистостенные клетки нижнего эпидермиса, диацитный тип устьичного аппарата; простые волоски; эфриромасличные железки с большими головками с 6-8 эпителиальных клеток. Перспективным является использование установленных основных морфолого-анатомических диагностических признаков живучки ползучей травы для разработки проекта методов контроля качества лекарственного растительного сырья.

КЛЮЧЕВЫЕ СЛОВА: живучка ползучая; морфолого-анатомические признаки; листья; стебель; цветки.

S. V. Maliuvanchuk A. R. Grytsyk, M. V. Melnik IVANO-FRANKIVSK NATIONAL MEDICAL UNIVERSITY

\section{INVESTIGATION OF MORPHOLOGICAL AND ANATOMICAL SIGNS OF GRASS AJUGA R.}

\section{Summary}

Introduction. Actual task is to conduct modern pharmacy of medicinal plants research, has centuries-old experience of use. The level of study of plants of the genus of the throat, growing on the territory of Ukraine is insufficient. An actual task of modern pharmacy is keeping researching the medicinal plants, which have centuries-old experience of use. Perspective objects for phytotherapy are representatives of the Ajuga L. genus, which are traditionally used in traditional and folk medicine in many countries for the treatment of the stomach diseases, urolithiasis, otitis, stomatitis, gallstone disease, inflammation of the uterine appendages, and also as an antimal arial and as a drug for improving metabolism. That is why a special interest is paid to the Ajuga reptans L. species, which is characteristic by a high content of the biologically active substances with anti-inflammatory, hemostatic, antioxidant effects. Perspective is the study of general and distinctive morphological and anatomical diagnostic signs of the structure of the plant material of the studied species of the genus Ajuga R. flora of Ukraine.

The aim of the study - to establish morphological anatomical signs of herb Ajuga R. for the allocation of diagnostic features.

Research Methods. For researches we used air dry and freshly harvested and fixed in the mixture glycerolethanol-water (1:1:1) plant material.The research was carried out using well-known methods using microscopes LOMO P-1 and L.4 ().The obtained data was recorded using schematic drawings and photographs taken by the camcorder Canon A 720 IS.

Results and Discussion. As a result of macro and microscopic analysis diagnostic features of leaves, grass petals are established Ajuga reptans.

Conclusions. By the method of macroscopic analysis external signs of Ajuga reptans L. raw material were investigated and anatomical diagnostic features of Ajuga reptans L. leaves were determined. By the method of microscopic analysis it was determined that cells of the upper epidermis are with slightly sinuous walls and cells of the lower epidermis are with sinuous walls; diacytic type of stomata; simple hairs; essential-oil glands with large heads of 6-8 epithelial cells. The prospect and practical value of the study is the use of the established basic morphological and anatomical diagnostic features of Ajuga reptans L. herb for the development of the project of quality control methods for medicinal plant material.

KEY WORDS: Ajuga reptans; anatomical characteristics; leaves; stem; flowers.

Адреса для листування: С. В. Малюванчук, Івано-Франківський національний медичний університет, вул. Галицька, 2, ІваноФранківськ, 76018, Україна, e-mail: sv_malyv@ukr.net. 